Рибидайло А. А., канд. техн. наук., ст. наук. співроб.

Центр воєнно-стратегічних досліджень Національного університету оборони України імені Івана Черняховського, Київ

\title{
Концептуальна модель управління кар’срою військовослужбовців Збройних Сил України
}

Резюме. Розглянуті питання обгрунтування пропозицій щодо розроблення концептуальної моделі управління кар'єрою військовослужбовців Збройних Сил України.

Ключові слова: концептуальна модель; управління кар'єрою; персонал збройних сил.

Постановка проблеми. Сутність управління кар'єрою військовослужбовців, як і управління кадровими ресурсами взагалі, полягає у забезпеченні комплектування Збройних Сил (3С) України особовим складом відповідної компетенції для досягнення ними визначених цілей $[1,2]$. Основне завдання управління людськими ресурсами полягає у пошуку, ефективному збереженні i відтворенні, спрямованому на формування і раціональне використання професійно підготовлених та вмотивованих особистостей, які відповідають потребам національної безпеки та оборони України.

Управління кар'єрою-заходи, які проводяться службами персоналу щодо планування, мотивації, супроводження та контролю кар'єрного розвитку персоналу відповідно до цілей, потреб і можливостей ЗС та конкретної особи.

Кадрові ресурси-особовий склад 3С України, який має необхідну професійну підготовку, знання та вміння для ефективного виконання завдань за призначенням.

Людські ресурси збройних сил - це громадяни України (частина трудових ресурсів держави), яка включає [3]:

постійний склад - особовий склад військових частин, органів військового управління та керівництва збройними силами;

змінний склад - особовий склад, який проходить навчання або підвищення кваліфікації в закладах освіти з відривом від виконання функціональних обов'язків за посадою (курсанти, слухачі, ад’юнкти, докторанти);

людські резерви ЗС України, а також ту частину кадрів, що знаходиться в запасі.

На сьогодні, система кадрового менеджменту (СКМ) ЗС України не забезпечує достатній рівень управління індивідуальною

кар'єрою військовослужбовців, планування та розвиток якої у загальній сукупності в масштабах збройних сил, надавав би можливості планування потреби збройних сил у персоналі на середньострокову та довгострокову перспективу, певної категорії, рівня організаційної ієрархії.

На якість комплектування збройних сил особовим складом впливає [4]:

невизначеність перспективного складу військ (сил), показників чисельності військовослужбовців за всіма категоріями, ВОС, спеціалізаціями та військовими званнями відповідно до перспективної структури збройних сил; відсутність затверджених перспективних штатів складу військ (сил) збройних сил;

відсутність детальної інформації про перспективний розподіл посад за ВОС, штатно-посадовими категоріями (ШПК) військовослужбовців.

Недосконалість існуючих підходів, а також відсутність єдиного методологічного підгрунтя щодо раціонального вирішення завдань 3 комплектування $3 \mathrm{C}$ України підготовленим особовим складом у середньостроковій та довгостроковій перспективі, докорінно впливає на питання зростання професіоналізації війська відповідності до стандартів НАТО. Особливу актуальність професіоналізація персоналу набуває в сучасних умовах ведення збройної боротьби, головними критеріями якої, на поточний момент, $\epsilon$ майстерне володіння сучасними засобами озброєння та військової техніки, досконале управління боєм (операцією) 3 метою виконання завдання, та максимально можливого збереження життя особового складу. Зважаючи на імовірні 
сценарії застосування збройних сил, та можливі варіанти організаційної структури, існуе необхідність у розробленні концептуальної моделі управління кар'єрою військовослужбовців, яка б дала змогу вирішувати завдання 3 комплектування 3С України підготовленим особовим складом у середньостроковій i довгостроковій перспективі, на основі врахування індивідуального підходу у СКМ щодо планування та розвитку кар'єри військовослужбовців.

Аналіз останніх досліджень i публікацій. 3 аналізу зарубіжної літератури значний інтерес являють собою підходи до управління персоналом збройних сил провідних держав світу (ПДС), система кадрового менеджменту яких побудована за методологією управління персоналом на основі моделі HRM FRAM (Human Resources (Manpower) Framework Model) [5]. Ця модель передбачає усі складові життєвого циклу управління персоналом, адміністрування, планування на довгострокову та короткострокову перспективу, але основна увага приділяється процесам набору, утримання, розвитку, наступництва та мотивації персоналу. Сутність зазначених процесів полягають у раціональному використанні кадрового потенціалу, де найбільший інтерес являє собою використання наукових методів під час прийняття кадрових рішень, реалізованих на основі застосування провідних інформаційних технологій. Основними цілями концепції HRM FRAM є “створення підрозділу, який містить підготовлених людей, на відповідних посадах, у визначений час", одним 3 важливих компонентів якої $є$ врахування вподобань персоналу. Про це також свідчать трансформаційні перетворення процесів управління кар'єрою в збройних силах США, іменовані як ATAP (The Army Talent Alignment Process) [6], що в перекладі означає процес узгдження компетентностей військових спеціалістів. АТАР включає процеси набору, розвитку та просування по службі військовослужбовців, яка поряд 3 оцінкою компетентності, навичок та морально-ділових якостей враховує уподобання військовослужбовців, що надає більше переваг військовослужбовцям у розвитку професійної кар'єри.

Так само, це надає можливості кадровим органам організовувати заходи 3 планування та розвитку як індивідуальної кар'єри військовослужбовців, так i планування комплектування персоналом організаційної структури збройних сил на середньострокову та довгострокову перспективу, з урахуванням імовірних загроз національній безпеці, імовірної структури збройних сил та набутих професійних компетентностей персоналу. Утримання персоналу здійснюється завдяки гнучкій системі мотивації на основі моніторингу стану світового ринку праці, де розроблена система бонусів та соціальних пакетів надають розширені соціальні, матеріальні та фінансові можливості у порівнянні до працівників цивільного сектору.

У роботі [7] автором проведено аналіз технології кадрового менеджменту, та на основі аналізу основних процесів управління персоналом, державної кадрової політики кожної країни відтворено стратегічну модель кадрового менеджменту, у якій визначено основні напрями, форми i методи забезпечення збройних сил кваліфікованими кадрами.

Аналіз вітчизняної наукової літератури свідчить про підвищений інтерес до питань удосконалення процесів управління персоналом, управління діловою кар'єрою. Це пояснюється процесами демократизації суспільства, динамічного оновлення системи управлінських відносин, які в останні роки набирають нових якостей, впровадження в державних та комерційних організаціях західних стандартів управління персоналом. У роботі [8] розглянуто теоретичні та прикладні аспекти управління персоналом, де особливу увагу заслуговують питання розвитку та управління кадровим потенціалом підприємства персоналом, зокрема, що стосується державної політики розвитку трудового потенціалу.

У роботі [9] проаналізовано основні концептуальні підходи розвитку персоналу організації, де автор розподіляє їх за складовими системної, процесної та культурологічної направленості. Також запропоновано комплексну модель розвитку персоналу організації.

У роботі [4] автором проведено аналіз проблем управління кар'єрою військовослужбовців Збройних Сил України як у мирний час, так i в особливий період. Запропоновано шляхи їх розв'язання 3 урахуванням набутого досвіду під час проведення антитерористичної операції.

Аналіз наведених праць свідчить про достатнє наукове підгрунтя 3 удосконалення системи кадрового менеджменту ЗС України, проте жодна 3 них не надає теоретичних i 
науково-методологічних положень щодо концептуальної моделі управління кар'єрою військовослужбовців, зважаючи на специфіку діяльності та основні завдань, які покладаються на ЗС України.

Мета статті. Обгрунтування пропозицій щодо розроблення концептуальної моделі управління кар'єрою військовослужбовців Збройних Сил України.

Виклад основного матеріалу. Сучасний стан теорії і практики військової кадрової політики доцільно розглядати стосовно завдань кадрового забезпечення збройних сил. Кадрова політика передбачає формування і реалізацію стратегії кадрового забезпечення військових формувань 3 метою створення умов для гарантованого та якісного комплектування збройних сил персоналом, спроможним на виконання завдань за призначенням і його ефективне використання.

Стратегічне управління людськими ресурсами - цілеспрямована скоординована діяльність керівників та фахівців кадрових органів щодо формування та ефективного використання сукупного трудового потенціалу, яка включає розроблення концепції і стратегії кадрової політики, принципів i методів формування системи управління людськими ресурсами (рис. 1).

Стратегія управління людськими ресурсами - це визначення шляхів розвитку необхідної компетенції всього персоналу i кожного іiі співробітника. Управління людьми $є$ основою управління організацією.

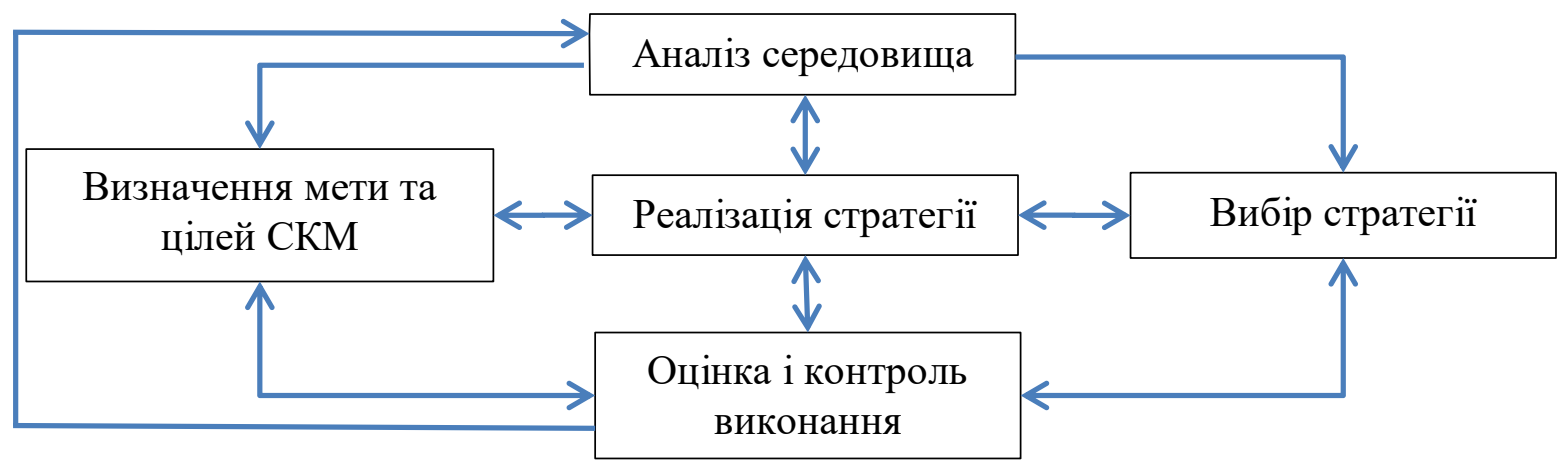

Рис. 1. Структура стратегічного управління людськими ресурсами

Особливості системи управління персоналом 3С України. Вихідними даними для здійснення управління персоналом ЗС України $є$ результати оборонного планування, що здійснюється Головним управлінням оборонного планування Генерального штабу 3С України. До того ж кадрову роботу стосовно управління персоналом 3С України можна структурувати за такими компонентами: облік всіх категорій населення України стосовно військового обов'язку, адміністрування персоналу, набір та розвиток персоналу, формування аналітичної звітності.

На сьогодні облік особового складу здійснюється згідно з керівними документами та ведеться за формами, перелік яких затверджено відповідними відомчими нормативними документами.

Компонента "Адміністрування персоналу” містить 20 підпроцесів, які можна розділити на групи:

прийняття на військову службу, роботу (всі категорії персоналу - всього 6 підпроцесів);

присвоєння військових звань і рангів державним службовцям, призначення на посаду та просування по службі персоналу всього 5 підпроцесів;

відпустки та відрядження (всі категорії кадрового резерву - всього 5 підпроцесів); звільнення 3 військової служби, роботи (всі категорії кадрового резерву - всього 4 підпроцеси).

Компонента "Набір та розвиток персоналу" містить 8 підпроцесів, 3 яких 4 передбачають урахування цілей, потреб i можливостей ЗС та конкретної особи. Розвиток персоналу передбачає застосування певних науково-методичних підходів щодо управління кар'єрою військовослужбовців.

Компонента "Формування аналітичної звітності” містить 5 підпроцесів і передбачає використання актуальної бази даних та безпосередньо пов'язана 3 результатами оборонного планування.

Система кадрового менеджменту Збройних Сил України має ієрархічну структуру. На кожному рівні ієрархії вирішуються визначені завдання стосовно комплектування військових формувань 
особовим складом с потрібними компетенціями.

Загальну структурно-логічну схему управління персоналом наведено на рис. 2.

Наведені на рис. 2 терміни мають такі тлумачення:

підготовка кадрів-процес підготовки громадян до військової служби, навчання (здобуття відповідних ступенів освіти) особового складу, удосконалення його професійних якостей відповідності до потреб та завдань збройних сил; планування персоналу у збройних силах цілеспрямований процес щодо визначення необхідної кількості персоналу, підготовленого до виконання завдань у визначений строк у потрібному місці в мирний та воєнний час;

кадрова робота-діяльність органів військового управління, спрямована на реалізацію цілей і завдань військової кадрової політики стосовно добору, планування, підготовки, розстановки та раціонального використання кадрів;

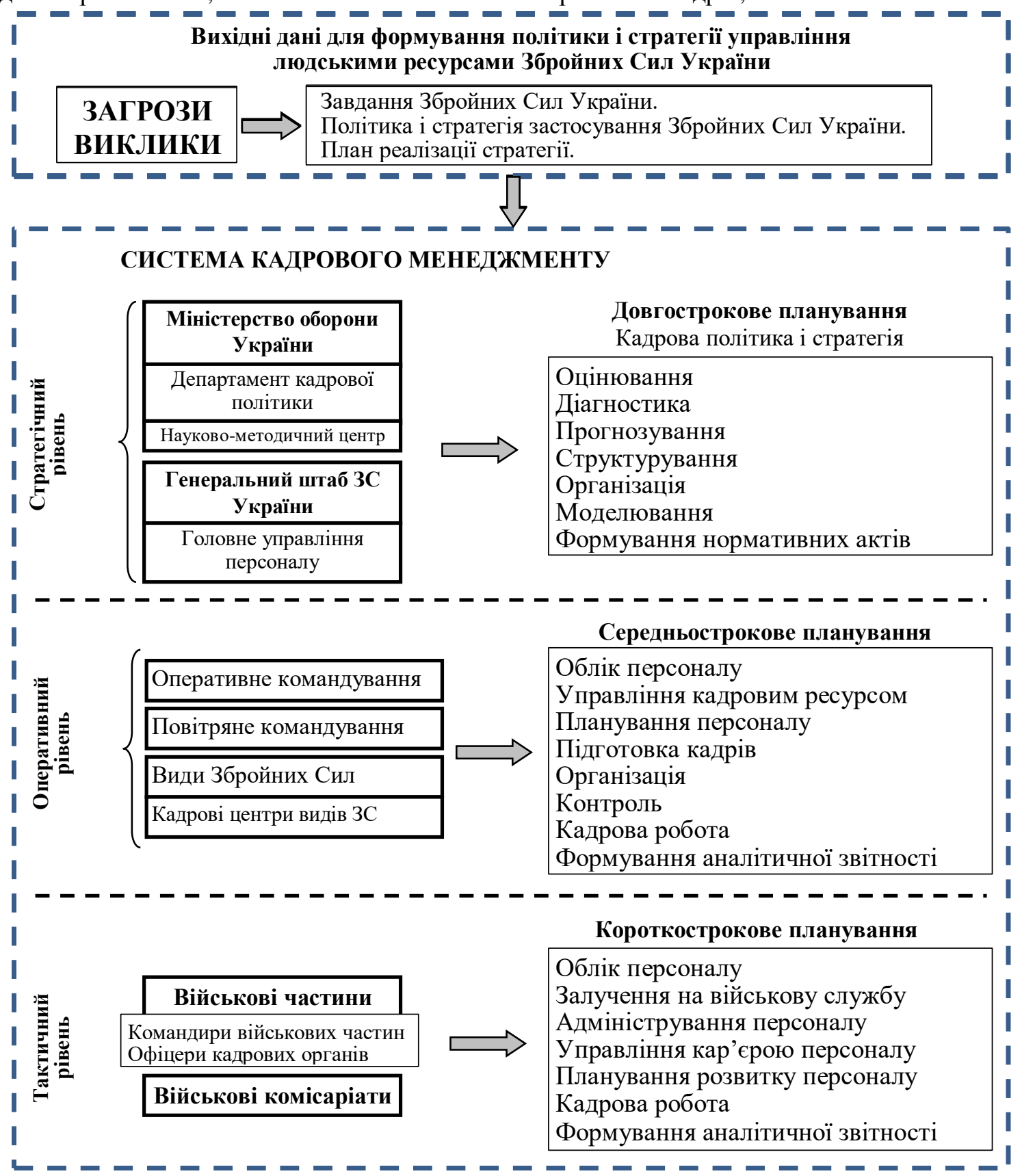

Рис. 2. Система управління персоналом ЗС України

діагностика - процес, який передбачає порівняння стану об'єкта дослідження 3 певною нормою або еталоном для виявлення відхилень. Методи діагностики можуть суттєво розрізнятися залежно від природи об'єкта дослідження і поділяють на чотири групи: аналітичні, експертні, лінійного програмування, динамічного програмування. Оперативна діагностика орієнтована на обгрунтування поточних управлінських 
рішень. Стратегічна діагностика - оцінювання ефективності обраної стратегії діяльності та дослідження стратегічних позицій підприємства за окремими напрямами його діяльності. Ретроспективне, оперативне, комплексне дослідження функціонування Системи кадрового менеджменту Збройних Сил України необхідне для обгрунтування його політики на майбутнє;

залучення на військову службу - процес вирішення завдань із комплектування збройних сил військовослужбовцями відповідної якості і кількості, що включає комплекс заходів щодо професійної орієнтації, відбору та прийняття (призову) громадян на військову службу.

Аналізуючи структуру Системи кадрового менеджменту Збройних Сил України та завдання, які вирішуються на кожному рівні організаційної ієрархії (рис. 2), можна дійти висновку про доцільність застосування технології стратегічного управління персоналом.

Узагальнюючи дані джерел можна дати таке визначення кадрової стратегії динамічна модель доцільної кадрової діяльності 3 підготовки, розстановки та раціонального використання висококваліфікованих кадрів, що враховує вплив факторів зовнішнього і внутрішнього середовищ.

Довідка. Динамічна модель системи сукупність співвідношень, що визначають вихід системи залежно від входу та стану системи.

Динамічна модель відтворює зміни об'єкта, які відбуваються 3 плином часу, або особливості функціонування об'єкта. Динамічні моделі називають також функціональними. Динамічне моделювання використовується для опису поведінки об'єкта в будь-який довільний змінний момент часу. У математичному моделюванні динамічних систем виділяють три основні частини:

емпіричну - фактичні дані, що отримуються в експериментах i спостереженнях, а також дані 3 первинної систематизації;

теоретичну частину - визначаються основні концепції для об'єднання й пояснення з єдиних позицій емпіричні закономірності та явища;

математична - конструює моделі для перевірки основних теоретичних концепцій, а також методи обробки експериментальних даних, планування експериментів i спостережень.
Кадрова стратегія:

визначається метою організації;

впливає на зміни структури (цільової, організаційної, функціональної) кадрової служби;

заснована на уявленнях про іiі стан в минулому, сьогоденні i прогнозованому майбутньому;

задається абстрактно заданою нормою (програмою, проєктом, планом, законодавчими і нормативними документами).

Кадрова стратегія розробляється відповідно до вимог об'єктивних законів управління, правилами їх реалізації в практичній діяльності і організовує способи діяльності людей по досягненню ними узгоджених цілей. Крім того, вона впливає на структурні і поведінкові взаємозв'язки підрозділів та працівників підприємства, організовує системну діяльність по досягненню кадрових цілей.

До того ж раціональна структура організації кадрової діяльності передбачає:

реальні взаємозв'язки між персоналом управління і їх діяльністю, які відображаються в схемах організаційних структур і посадових обов'язках;

кадрову політику і методи управління персоналом;

повноваження і функції персоналу на ієрархічних рівнях управління.

3 огляду на положення теорії організації [10], під час створення i вдосконалення підприємств на стратегічному рівні (макрорівні) вивчають умови та передумови їх функціонування, загальну ефективність i можливості для досягнення цілей, досліджують варіанти оптимізації структури, прогнозують структуру персоналу організацій. $\mathrm{Ha}$ тактичному рівні (мікрорівні) досліджуються: поведінка індивідуумів і груп; вплив базових та індивідуальних цінностей, професійної освіти, мотивації та особистих якостей на стратегічне і тактичне управління.

Отже, важливим у роботі з людськими ресурсами є встановлення та використання індивідуальних здібностей кандидатів на посаду (навчання) відповідно до стратегічних цілей організації для оволодіння новою технікою й технологіями, інтеграція потреб і мотивів людини, іiі професійної спрямованості з інтересами організації.

Для вирішення означеного завдання потрібно прийняти концептуальну модель управління кар'єрою персоналу збройних сил. У Тлумачному словнику зі штучного інтелекту наведено таке визначення: 
концептуальна модель - це модель предметної області, що складається 3 переліку взаємопов'язаних понять, які використовуються для опису цієї області, разом 3 властивостями i характеристиками, класифікацією цих понять, за типами, ситуаціями, ознаками в даній області і законів протікання процесів в ній.

У фахових джерелах наводяться інші трактування поняття “концептуальна модель", проте всі визначення зводяться до такого тлумачення: концептуальна (змістовна) модель - це структура системи, яка моделюється, властивості пї елементів і причинно-наслідкові зв'язки, що властиві системі і суттєві для досягнення мети моделювання.

Концептуальна модель управління кар'єрою військовослужбовців наведена на рис. 3.

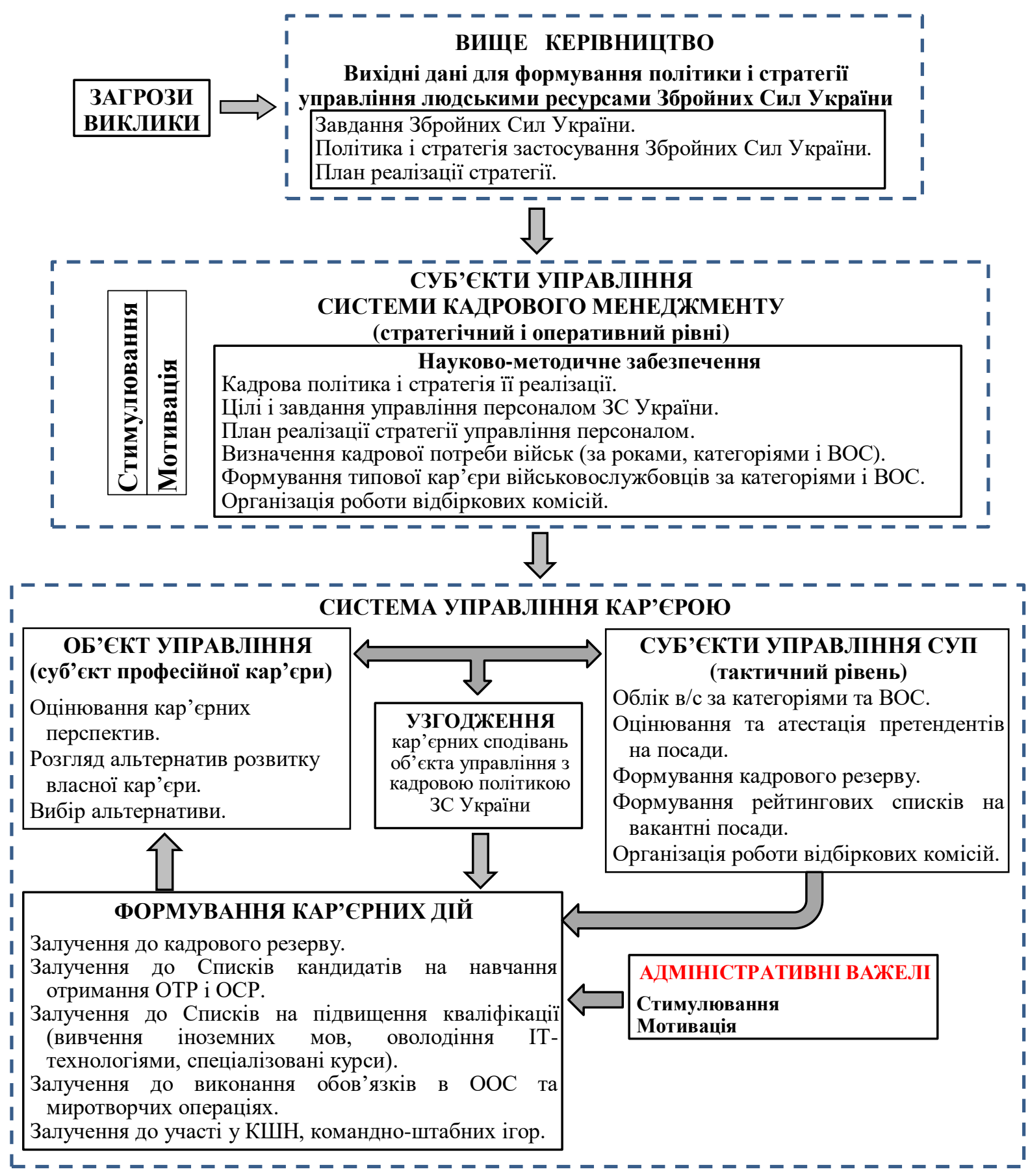

Рис. 3. Концептуальна модель управління кар'єрою військовослужбовців

Надалі потрібно розробити часткові моделі: індивідуальної кар'єри, просування по службі, узгодження кар'єрних сподівань, стимулювання i мотивації, які у сукупності можна розглядати як теоретико-дослідницької моделі i використовувати для поліпшення 
ефективності управління персоналом ЗС України, за допомогою детального дослідження означених складових.

Процес управління кар'єрою визначається як цілеспрямована взаємодія на формування посадового та професійного зростання військовослужбовця відповідно до внутрішніх потреб військового відомства, а також потенціалу й очікувань самого військовослужбовця. Оскільки таке визначення акцентує увагу на необхідності брати до уваги не лише потреби військової організаційної структури, а й кожного військовослужбовця, то очевидним є той факт, що управління кар'єрою військовослужбовців має грунтуватися на обов' язковому врахування таких положень:

військовослужбовці мають отримати визначення як особистості 3 унікальними потребами, бажаннями та здібностями;

персонал Збройних Сил України більше мотивує та військова організаційна структура, яка відповідає їх прагненням і потребам;

військовослужбовці можуть професійно зростати, змінюватися та знаходити нові напрями для діяльності, якщо надати їм належні, відповідні можливості, заохочення і керівництво.

Висновок. У стратегічному управлінні кар'єрою військовослужбовців доцільно виділити статичну i динамічну складові. Центральної складовою частиною стратегії $\epsilon$ персонал, а головним системоутворюючим фактором - мета діяльності організації. У процесі стратегічної діяльності - розв'язують проблеми, а тактичної - повсякденні завдання, визначені стратегією. Сучасну теорію управління персоналом необхідно адаптувати до конкретної предметної області.

Подальші дослідження доцільно зосередити на обгрунтуванні функціональної моделі управління кар'єрою та синтезу на ii основі математичної моделі управління кар'єрою військовослужбовців.

\section{СПИСОК ВИКОРИСТАНОЇ ЛІТЕРАТУРИ}

1. Про затвердження Концепції військової кадрової політики у ЗС України на період до 2020 року : наказ Міністерства оборони України від 26.06.2017 p. № 342 .

URL:

http://www.mil.gov.ua/diyalnist/kadrovapolitika/konczepcziya-kadrovoi-politiki-v-zbrojnihsilah-ukraini. (дата звернення: 12.05.2020).

2. Ветров В. І., Гаврилов О. С. Кадрова політика як система управління кадровими ресурсами. Військова освіта. Київ, 2004. № 9. С. 125-128.

3. Медвідь А. П., Базарний В. Т., З Захаров О. Б. Кадрова політика в Збройних Силах України: визначення, стан, можливі перспективи розвитку. Вісник воєнної розвідки. Київ, 2010. № 20. С. 25-29.

4. Коваль О. В. Проблеми управління кар'єрою військовослужбовців Збройних Сил України в мирний час й особливий період та шляхи їх вирішення. Збірник наукових праць Національной академії державного управління при Президентові України. Актуальні проблеми державного управління. Одеса, 2017. №4. С. 101110.

5. Nato Human Resources (Manpower) Management. RTO-TR-SAS-059.

URL: http://citeseerx.ist.psu.edu/viewdoc/ download?rep=rep1\&type=pdf\&doi=10.1.1.222.748 (дата звернення: 10.04.2020).

6. The Army Talent Alignment Process (ATAP). URL: https://talent.army.mil/atap/ (дата звернення: 10.04.2020).

7. Вєтров В. І., Вранешич О. В. Модель кадрового менеджменту. Оборонний вісник. 2020. № 3. C. 16-21.

8. Управління персоналом i економіка праці: теорія та практика : монографія / за заг. ред. Драган О. І. Київ : Вініченко, 2014. 298 с;

9. Петрович Й. М., Винничук Р. О. Концептуальні підходи до розвитку персоналу організації. Економічний часопис-XXI. Київ, 2014. № 3-4 (2). C. 27-30.

10. Теория организации : конспект лекций. URL: http://www.diagram.com.ua/info/konspekti-

shpargalki/konspekti-shpargalki290.shtml (дата звернення: 26.04.2020).

11. Види стимулювання праці і їх основний зміст : підручники для студентів онлайн. URL: https://stud.com.ua/26200/menedzhment/vidi_stimul yuvannya_pratsi_osnovniy_zmist (дата звернення: 28.04.2020).

12. Данканич M. Шість способів мотивації персоналу від західних експертів. URL: http://iqholding.com.ua/articles/6-sposobivmotivatsiï-personalu-vid-zakhidnikh-ekspertiv (дата звернення: 28.04.2020).

Стаття надійшла до редакційної колегії 28.05.2020 


\section{Conceptual model of servicemen career management of the Armed Forces of Ukraine} Annotation

The essence of career management of military personnel, as well as human resource management is to ensure that the Armed Forces of Ukraine are staffed with personnel of the appropriate competence to achieve their goals. The main task of human resources management is to find, effectively preserve professionally trained and motivated individuals who meet the needs of National Security and Defense of Ukraine.

Today, the Human Resource Management System does not provide the necessary planning and management of individual careers and their further development at the proper level. The development of the Human Resource Management System is necessary for a more accurate planning of Armed Forces needs in personnel of certain qualifications for the medium and long term use.

Human resource management strategy is the definition of ways to develop the necessary competence of all personnel and each of its employees individually. Human resource management is the foundation of management in any organization. Analyzing the structure of the Personnel Management System of the Armed Forces of Ukraine and its tasks, it can be concluded that it is advisable to use the technology of Strategic Personnel Management.

In the system of Strategic Career Management of military personnel, it is advisable to single out the static and dynamic components. The main part of the strategy is personnel, and the main system-forming factor is the goal of the organization. In the process of strategic activity, they solve problems, and tactical everyday tasks, determined by the strategy. The modern theory of personnel management must be adapted to a specific subject area.

Keywords: conceptual model; career management; personnel of the Armed Forces. 